\title{
ABSENTEEISM AND PRESENTEEISM IN RHEUMATOID ARTHRITIS, AXIAL SPONDYLOARTHRITIS, AND PSORIATIC ARTHRITIS: RELATIONSHIP WITH FATIGUE AND CLINICAL PARAMETERS
}

\author{
ROMATOİD ARTRITT, AKSIYYEL SPONDILOARTRİT VE PSÖRİATIK ARTRİTTE İŞ GÜCÜ \\ KAYBI: YORGUNLUK VE DİĞER KLINNIK PARAMETRELERLE İLIŞKİSI
}

İsmihan SUNAR ${ }^{1}$, Yeşim GARIP², Şebnem ATAMAN ${ }^{3}$

\section{ABSTRACT}

AIM: Rheumatic diseases cause economic burden due to apparently costs along with indirect costs including productivity loss. This study aims to assess work productivity in axial spondyloarthritis (SpA), rheumatoid arthritis (RA), and psoriatic arthritis (PsA), and determine its relation with fatigue, disease activity, depression, and quality of life.

MATERIAL AND METHOD: This cross-sectional study included $42 \mathrm{SpA}, 36 \mathrm{PsA}, 34 \mathrm{RA}$ patients, and 30 controls. The number of swollen and tender joints, erythrocyte sedimentation rate, and $\mathrm{C}$-reactive protein were recorded. Disease activity was determined by the Bath Ankylosing Spondylitis Disease Activity Index for SpA, Disease Activity in Psoriatic Arthritis for PsA, and Disease Activity Score-28 for RA. The Stanford Health Assessment Questionnaire, Short Form-36, Fatigue Symptom Inventory, and Beck Depression Inventory were performed. Pain was measured using the Visual Analog Scale. The Work Productivity and Activity Impairment scale was administered for work productivity. Logistic regression analysis was used to determine factors affecting work productivity. Correlations were assessed by Spearman's correlation coefficient.

RESULTS: The rate of employment was $83.3 \%$ in SpA, 52.8\% in PsA, $61.8 \%$ in RA, and $93.3 \%$ in controls. The percentage of absenteeism was higher in SpA and PsA. Percentage of presenteeism, percent total work impairment caused by health problems, and percent activity impairment due to health problems were higher in SpA, PsA, and RA patients than controls $(\mathrm{p}<0.05)$. Regression analysis revealed the impact of functionality on percentage of absenteeism and presenteeism; and pain severity on absenteeism $(\mathrm{p}<0.001$, $\mathrm{p}=0.02$, and $\mathrm{p}=0.02$ respectively). Age, gender, and disease activity had no impact on absenteeism or presenteeism ( $\mathrm{p}>0.05)$.

CONCLUSION: We have found high percentage of presenteeism in all patient groups and high percentage of absenteeism in SpA and PsA patients compared to controls. We observed impact of functionality on percentage of absenteeism and presenteeism; whereas pain affected the percentage of absenteeism.

Keywords: absenteeism; presenteeism; psoriatic arthritis; rheumatoid arthritis; spondyloarthritis; work productivity

${ }^{1}$ Aydın State Hospital, Rheumatology Clinic, Aydın, Turkey

2 Ankara Sincan Başak Medical Center, Physical Medicine and Rehabilitation Clinic, Ankara, Turkey

${ }^{3}$ Division of Rheumatology, Department of Physical Medicine and Rehabilitation, Ankara University School of Medicine, Ankara, Turkey

Geliş Tarihi / Submitted : Mayıs 2021 / March 2021

Sorumlu Yazar / Corresponding Author:

Ismihan SUNAR

Mimar Sinan Boulevard No:32/8 Efeler, Aydın, Turkey

Gsm: +905054291339

E-mail: dr.ismihan@gmail.com

ÖZET

AMAÇ: Romatizmal hastalıklar doğrudan maliyetlerin yanı sıra iş gücü kaybına bağlı indirekt maliyetler ile de ekonomik yüke neden olurlar. Bu çalışmada Romatoid Artrit (RA), Aksiyel Spondiloartrit (SpA) ve Psöriatik Artrit (PsA) hastalarında iş gücü kaybının değerlendirilmesi ve yorgunluk, hastalık aktivitesi, depresyon ve hayat kalitesi ile ilişkisinin araştırılması amaçlanmıştır.

GEREÇ VE YÖNTEM: Bu kesitsel vaka-kontrol çalışmasına $42 \mathrm{SpA}$, 36 PsA, 34 RA hastası ve 30 sağlıklı kontrol dahil edilmiştir. Hassas ve şiş eklem sayısı, eritrosit sedimentasyon hızı (ESH), C-Reaktif protein düzeyleri kaydedildi. Hastalık aktivitesinin belirlenmesi amaciyla RA hastalarında DAS28 (Disease Activity Score 28), SpA hastalarında BASDAI (Bath Ankylosing Spondylitis Disease Activity Index), PsA için ise DAPSA (Disease Activity in Psoriatic Arthritis for PsA) kullanıld. Tüm hasta gruplarına fonksiyonel durum, hayat kalitesi, yorgunluk ve depresyonun değerlendirilmesi için HAQ (The Stanford Health Assessment Questionnaire), Short Form-36 (SF-36), Yorgunluk Semptom Envanteri (Fatigue Symptom Inventory) ve Beck Depresyon anketi uygulandı. Ağrı görsel analog skala ile, iş gücü kaybı ise WPAI (Work Productivity and Activity Impairment) ile değerlendirildi.

BULGULAR: Calıșma oranı SpA hastalarında \%83,3, PsA'da \%52,8, RA'da \%61,8 ve kontrollerde $\% 93,3$ olarak belirlendi. İște var olamama sorunu (presenteeism) ve ișe devamsizlik (absenteeism) SpA ve PsA hastalarında kontrollerden daha yüksekti. İște var olamama yüzdesi, sağlık problemlerine bağlı toplam is gücü kaybı ve sağllk problem nedenli aktivite bozukluk yüzdeleri RA, PsA ve SpA hastalarında kontrollerden yüksekti $(\mathrm{p}<0.05)$. Regresyon analizi fonksiyonelliğin absenteeism ve presenteeism üzerine, ağrı şiddetinin ise absenteeism üzerine etkisi olduğunu gösterdi (sırasıyla $\mathrm{p}<0.001, \mathrm{p}=0.02$, ve $\mathrm{p}=0.02)$. Yaş, cinsiyet ve hastalık aktivitesinin absenteeism ve presenteeism üzerinde etkisi olmadığı görüldü ( $\mathrm{p}>0.05)$.

SONUÇ: Çalışmamızda kontrollerle kıyaslandığında RA, SpA ve PsA hastalarında yüksek iște var olamama sorunu ve SpA ve PsA hastalarında artmış işe devamsızlık yüzdesi saptadık. Fonksiyonel kapasitenin işe devamsızlık ve işte var olamama sorunu üzerine, ağrı düzeyinin ise işe devamsızlık üzerine etkisi olduğu gözlendi.

Anahtar Kelimeler: absenteeism; presenteeism; psöriatik artrit; romatoid artrit; spondiloartrit; iş gücü

Ethics committee approval was obtained from Ankara University Ethics Committee with date of 16 April 2018 and number of 07-431-18. All participants gave informed consents.
Kabul Tarihi / Accepted : Ağustos 2021 / August 2021

Yazar Bilgileri /Author Information:

Ismihan SUNAR (ORCID : 0000-0002-4435-5677,

Yeşim GARIP (ORCID : 0000-0002-8602-2934) E-mail: dryesimgarip@gmail.com, Sebnem ATAMAN（ORCID : 0000-0003-3570-3825) E-mail: ataman.sebnem@gmail.com 


\section{INTRODUCTION}

The socioeconomic effects of rheumatic diseases have been increasingly realized in recent years. Inflammatory rheumatic diseases have a financial load on individuals and society due to inflammation, joint involvement, functional loss, and pain. The costs related to rheumatic diseases include hospitalization, drug consumption, laboratory tests, imaging, surgeries, rehabilitation, and expenditure due to disability such as transport, orthotics, and nursing(1). Biological disease-modifying anti-rheumatic drugs (DMARDs) have ushered a new era in the treatment of rheumatic diseases; however, these carry an increased economic load with yearly costs of $\$ 25,000$ to $\$ 40,000(2)$. Besides, there are indirect costs associated with rheumatic diseases: 1 ) productivity loss due to disease-related absence from work (absenteeism), and 2) productivity loss resulting from reduced work performance related to the disease (presenteeism)(1).

Work productivity is a result of various factors such as disease activity, functional disability as well as socioeconomic factors, and is now accepted as an important outcome in rheumatic disorders(1). Several studies have been conducted to determine the burden of rheumatologic diseases on work productivity and quality of life(3-7) . In a study on rheumatoid arthritis (RA) patients, higher disease activity was found to be related to decreased work productivity and quality of life(3). A recent review on work productivity in patients with spondyloarthritis (SpA) have reported significant relationship between productivity impairment and increased disease activity and functional status(8). Another study on 107 patients with psoriatic arthritis (PsA) reported a $6.7 \%$ decrease in work productivity and significant association between work loss and fatigue(4). Fatigue is described as 'sense of long-lasting tiredness or effeteness which distresses the person'(9). Although fatigue is among the most handicapping symptoms in patients with rheumatic diseases, its relation with work productivity is scarcely known. Previous studies report that labor loss is negatively associated with the quality of life, physical role limitations, and pain(10). In the literature, there are no studies comparing work productivity loss across distinct rheumatic disorders employing a control group. Hence, we aimed to include three groups of rheumatic patients and controls to assess relationships between work productivity loss and other clinical parameters.

The aims of the present study are twofold: (i) to assess work productivity across three disease groups of SpA, RA, PsA, and healthy controls using the Work Productivity and Activity Impairment (WPAI), and (ii) to determine the relation of work productivity with fatigue, disease activity, depression, and quality of life in terms of social, emotional, and mental functioning. To the best of our knowledge, this study is the first to evaluate the association between productivity loss and fatigue in three different rheumatic patient groups along with a control group.

\section{MATERIAL AND METHOD \\ Patients}

A total of 112 patients (42 SpA, 36 PsA, and 34 RA) followed consecutively at the Outpatient Clinic of Rheumatology were enrolled in this cross-sectional study between May-December 2018. The control group consisted of 30 healthy subjects who were either the hospital staff or patients' companions. Exclusion criteria were being $<18$ years, pregnancy, having orthopedic or psychiatric disorders, severe systemic diseases such as cardiovascular, pulmonary, and renal diseases, and coexistent inflammatory diseases. Patient information regarding age, gender, and duration of the disease, erythrocyte sedimentation rate (ESR), and C-reactive protein (CRP) levels were documented. Written informed consent was obtained from all of the participants. The study protocol was ratified by the Ankara University School of Medicine Ethics Committee with date of 16 April 2018 and number of 07-431-18. The study was conducted in compliance with the decrees of the World Medical Association's Declaration of Helsinki.

Axial SpA was diagnosed based on the Assessment of SpondyloArthritis International Society (ASAS) classification criteria for axial SpA(11). Disease activity was monitored using the Bath Ankylosing Spondylitis Disease Activity Index (BASDAI)(12). BASDAI $>4$ was accepted to be active disease.

Psoriatic arthritis patients fulfilled the Classification Criteria for PsA (CASPAR)(13). Disease activity was measured by using the Disease Activity of Psoriatic Arthritis (DAPSA)(14). Measures between 0-4 were accepted as remission, 5-14 low, 15-28 moderate, and $>28$ as high disease activity.

Rheumatoid arthritis patients were diagnosed based on the American College of Rheumatology (ACR) / European League against Rheumatism (EULAR) Diagnostic Criteria(15). The number of swollen and tender joints were documented. Disease activity was measured using the quadrivariate Disease Activity Score-28 (DAS28). Measures under 3.2 were considered low, 3.2-5.1 as intermediate, and over 5.1 as high disease $\operatorname{activity}(16)$.

The severity of pain was calculated using a $10 \mathrm{~cm}$ VAS (Visual analog scale)-pain(17). The Stanford Health Assessment Questionnaire (HAQ) was used for determining the physical functioning in all patient groups (18). We used the Turkish versions of the Short Form-36 (SF36) for evaluating the quality of life (19) and Beck Depression Inventory (BDI) for determination of the depressive status (20).

Controls composed of hospital staff and patients' companions. The inclusion criterion was willing to participate in the study and exclusion criteria for controls were same as patients'. 


\section{Assessment of work productivity}

Work productivity was determined using the Turkish version of the Work Productivity and Activity Impairment General health (WPAI:GH), which was designed in 1993 by Reilly et al (21). It includes six answers (A) for self-administered questions which measure the influence of the health condition and disease symptoms on work productivity over last seven days: Are you currently employed?: Yes or no (A1); lost hours due to health problems (A2); lost hours due to other causes (A3); hours actually worked (A4), how much did your disease influence your productivity in the last seven days? (A5), how severely did your health condition influence your regular routine activities off the work in the last seven days? (A6). Using the answers to these questions, some parameters are obtained. These are: percent lost work time caused by health problems (percentage of absenteeism): (A2/(A2+A4) $\mathrm{x} 100$; percent impairment during working caused by health problems (percentage of presenteeism): (A5/10) $\mathrm{x} 100$; percent total work impairment caused by health problems (productivity loss): (A2/(A2+A4) + [1-(A2/ $(\mathrm{A} 2+\mathrm{A} 4)) \mathrm{x}(\mathrm{A} 5 / 10)]$; and percent activity impairment caused by health problems: A6/10.

\section{Assessment of fatigue}

The Turkish version of the Fatigue Symptom Inventory (FSI)(22) was used to assess fatigue. The FSI is a 14-item self-administered scale which has been designed in 1998(9) to evaluate the severity of fatigue (four questions), continuance (two questions), its interference with quality of life (seven questions), and daytime patterns of fatigue (one question). Interference subgroups demonstrate how much fatigue negatively influenced the person's daily tasks, concentration, and social and emotional functioning in the last week(9). Continuance subgroups assess the number of days fatigued and the amount of time fatigued(23).

\section{Statistical Analysis}

All analyses were accomplished using the Statistical Package for the Social Sciences-21.0 (SPSS-21.0) software. Distribution of data was assessed using the Shapiro Wilk test. Descriptive statistics [mean, standard deviation (SD), median, minimum, maximum, and frequencies] were used for demographics and clinical parameters. Because variables were not normally distributed, Kruskal Wallis and Mann Whitney U tests were performed to assess group differences. Chi-square test was used for determining categorical parameters and logistic regression analysis for the constituents influencing presenteeism and absenteeism. The presence of correlation was evaluated by Spearman's correlation coefficient. A measure of $\mathrm{p}<0.05$ was considered as statistically significant.

\section{RESULTS}

Forty-two patients with SpA (19 women, 23 men), 36 PsA (26 women, 10 men), 34 RA (22 women, 12 men), and 30 healthy controls (17 women, 13 men) were included. Mean age was $39.4 \pm 8.2,47.1 \pm 12.2$, and $50.1 \pm 10.8$ years in SpA, PsA, and RA patients, respectively. The mean age of RA and PsA patients were slightly higher than SpA patients. The mean disease activity scores were 3.6 \pm 2.2 (inactive disease according to BASDAI) in SpA patients, 14.6 \pm 11.0 (low disease activity according to DAPSA) in PsA patients, and 3.18 \pm 1.2 (low disease activity according to DAS28) in RA patients. Demographic and clinical data of the patients were given in Table 1.

In SpA group, 35 patients $(83.3 \%)$ were currently employed. In PsA and RA groups, 19 (52.8\%) and 21 (61.8\%) patients were active workers respectively. In controls, $28(93.3 \%)$ were actively working. The occupations of the patients and controls were given in Table 2.

Kruskal-Wallis test revealed that there was statistically significant difference in lost hours due to health problems (A2), percentage of absenteeism, percentage of presenteeism, percent total work impairment caused by health problems (productivity loss), and percent activity impairment caused by health problems among PsA, RA, and SpA groups ( $<<0.05$ for all). According to Mann-Whitney U test, SpA and PsA patients had significantly higher numbers of hours missed due to health problems (A2) compared to the controls ( $\mathrm{p}=0.001$, $\mathrm{p}=0.002$ respectively). Percentage of absenteeism was significantly higher in SpA and PsA patients than in the controls $(\mathrm{p}=0.002, \mathrm{p}=0.001$ respectively); percentage of presenteeism, percent total work impairment, and percent activity impairment caused by health problems were significantly higher in SpA, PsA, and RA patients than in the controls $(p<0.05$ for all) (Table 3$)$.

A logistic regression analysis was performed to examine absenteeism and presenteeism of patients with RA, PsA, and AS in order to evaluate the contribution of factors affecting the variables. Age, gender, functional status, disease activity, and disease duration were independent variables which can be considered as confounding factors. Hence, their contribution to the model was taken into account. Accordingly, dependent variables were absenteeism and presenteeism. The control group was not included in the analysis. The model was created with the "enter" method. While presenteeism decreased with increasing age, statistical significance was not observed $(p>0.05)$. As the functional status deteriorated, absenteeism and presenteeism increased about 0.4 times and there was statistical significance $(p<0.05)$. As the severity of pain increased, absenteeism increased about 0.3 times $(\mathrm{p}<0.05)$. Explanatory for the model applied for presenteeism is $45 \%$ while the model applied for absenteeism is $15 \%$. $\beta$ coefficients and adjusted R2 values were shown in Table 4.

A correlation analysis was performed for the linear relationship between WPI and fatigue, depression, and quality of life. All FSI and BDI subgroups were found 
to be positively, and SF-36 subgroups were negatively correlated with percentage of absenteeism, percentage of presenteeism, and percent total work impairment caused by hea lth problems (productivity loss) $(\mathrm{p}<0.05$ for all) (Table 5).

\section{DISCUSSION}

In the present study, we evaluated the productivity loss in patients with SpA, RA, and PsA using the WPAI. The rate of employment was $83.3 \%$ in SpA, $52.8 \%$ in PsA, and $61.8 \%$ in RA patients and significantly lower

\section{Table 1. Demographic and clinical data of the patients with $\mathrm{SpA}, \mathrm{RA}$, and PsA}

\begin{tabular}{|c|c|c|c|c|}
\hline & $\begin{array}{l}\text { SpA patients } \\
\text { (n: } 42)\end{array}$ & $\begin{array}{l}\text { PsA patients } \\
\quad(n: 36)\end{array}$ & $\begin{array}{l}\text { RA patients } \\
\quad(\mathrm{n}: 34)\end{array}$ & $\begin{array}{l}\text { Controls } \\
(\mathrm{n}: 30)\end{array}$ \\
\hline Age (years) Mean $\pm S D$ & $39.4 \pm 8.2$ & $47.1 \pm 12.2$ & $50.1 \pm 10.8$ & $40.9 \pm 9.7$ \\
\hline Gender (n, \% female) & $19(45.2 \%)$ & $26(72.2 \%)$ & $22(64.7 \%)$ & $17(56.7 \%)$ \\
\hline Currently employed (n, \%) & Yes $(35,83.3 \%)$ & Yes $(19,52.8 \%)$ & Yes $(21,61.8 \%)$ & Yes $(28,93.3 \%)$ \\
\hline Disease duration (months) $($ Mean \pm SD) & $92.61 \pm 83.77$ & $84.91 \pm 86.15$ & $122.59 \pm 107.82$ & \\
\hline $\begin{array}{l}\text { Pain (VAS, } 10 \mathrm{~cm} \text { ) [Median (min- } \\
\max )]\end{array}$ & $4.00(0.00-10.00)$ & $5.00(0.00-10.00)$ & $5.00(0.00-10.00)$ & \\
\hline $\begin{array}{l}\text { Disease activity [Median (min-max)] } \\
\text { (BASDAI/DAPSA/DAS28) }\end{array}$ & $3.40(0.00-8.60)$ & $19.5(4.00-64.00)$ & $2.90(0.90-5.87)$ & \\
\hline Functional status (HAQ) (Mean \pm SD) & $0.45 \pm 0.48$ & $0.49 \pm 0.52$ & $1.41 \pm 1.21$ & \\
\hline FSI-intensity [Median (min-max)] & $5.00(0.00-8.80)$ & $5.20(0.60-9.00)$ & $5.00(0.00-8.00)$ & \\
\hline FSI-duration [Median (min-max)] & $5.10(0.00-8.50)$ & $4.00(0.00-8.00)$ & $4.50(0.00-8.50)$ & \\
\hline $\begin{array}{l}\text { FSI-interference with quality of life } \\
{[\text { Median (min-max)] }}\end{array}$ & $3.80(0.00-9.50)$ & $3.50(0.00-9.00)$ & $4.50(0.00-7.40)$ & \\
\hline SF36 physical functioning [[Median & $75.00(25.00-100.00)$ & $70.00(15.00-100.00)$ & $65.00(15.00-100.00)$ & \\
\hline $\begin{array}{l}\text { SF36 role-physical [Median (min- } \\
\max ) \text { ] }\end{array}$ & $50.00(0.00-100.00)$ & $50.00(0.00-100.00)$ & $50.00(0.00-100.00)$ & \\
\hline SF36 bodily pain [Median (min-max)] & $45.25(0.00-100.00)$ & $55.00(5.00-100.00)$ & $45.00(12.50-100.00)$ & \\
\hline $\begin{array}{l}\text { SF36 general health [Median (min- } \\
\max ) \text { ] }\end{array}$ & $40.00(50.00-90.00)$ & $40.00(0.00-95.00)$ & $50.00(10.00-80.00)$ & \\
\hline SF36 vitality [Median (min-max)] & $47.50(5.00-85.00)$ & $55.00(5.00-75.00)$ & $35.00(15.00-80.00)$ & \\
\hline $\begin{array}{l}\text { SF36 social functioning [Median (min- } \\
\max )]\end{array}$ & $50.00(0.00-100.00)$ & $62.50(0.00-100.00)$ & $56.25(25.00-100.00)$ & \\
\hline $\begin{array}{l}\text { SF36 role-emotional [Median (min- } \\
\max )]\end{array}$ & $66.85(0.00-100.00)$ & $33.30(0.00-100.00)$ & $33.30(0.00-100.00)$ & \\
\hline $\begin{array}{l}\text { SF36 mental health [Median (min- } \\
\max ) \text { ] }\end{array}$ & $56.00(16.00-84.00)$ & $56.00(24.00-96.00)$ & $56.00(24.00-84.00)$ & \\
\hline BDI [Median (min-max)] & $7.00(0.00-30.00)$ & $10.00(0.00-30.00)$ & $11.5(0.00-23.00)$ & \\
\hline
\end{tabular}

RA: Rheumatoid Arthritis, SpA: Spondyloarthritis, PsA: Psoriatic arthritis, SD: Standard deviation, VAS: Visual Analog Scale, ESR: Erythrocyte sedimentation rate, CRP: C-reactive protein, BASDAI: Bath Ankylosing Spondylitis Disease Activity, DAPSA: Disease Activity Psoriatic Arthritis, HAQ: Stanford Health Assessment Questionnaire, DAS28: quadrivariate Disease Activity Score, FSI: Fatigue Symptom Inventory, SF36: Short Form-36, BDI: Beck Depression Inventory. Disease activity: BASDAI for SpA, DAPSA for PsA, and DAS28 for RA

Table 2. Employment and occupations of the patients and the controls

\begin{tabular}{|c|c|c|c|c|c|c|c|c|}
\hline & \multicolumn{2}{|c|}{$\begin{array}{l}\text { SpA patients } \\
\quad(\mathrm{n}: 42)\end{array}$} & \multicolumn{2}{|c|}{$\begin{array}{l}\text { PsA patients } \\
\quad(\mathrm{n}: 36)\end{array}$} & \multicolumn{2}{|c|}{$\begin{array}{l}\text { RA patients } \\
\quad(\mathrm{n}: 34)\end{array}$} & \multicolumn{2}{|c|}{$\begin{array}{l}\text { Controls } \\
\text { (n:30) }\end{array}$} \\
\hline & $\begin{array}{c}\text { Women } \\
(19,45.2 \%)\end{array}$ & $\begin{array}{c}\text { Men } \\
(23,54.8 \%)\end{array}$ & $\begin{array}{l}\text { Women } \\
(26,72.2 \%)\end{array}$ & $\begin{array}{c}\text { Men } \\
(10,27.8 \%)\end{array}$ & $\begin{array}{l}\text { Women } \\
(22,64.7 \%)\end{array}$ & $\begin{array}{c}\text { Men } \\
(12,35.3 \%)\end{array}$ & $\begin{array}{c}\text { Women } \\
(17,56.7 \%)\end{array}$ & $\begin{array}{c}\text { Men } \\
(13,43.3 \%)\end{array}$ \\
\hline $\begin{array}{l}\text { Currently } \\
\text { employed } \\
(\mathrm{n}, \%)\end{array}$ & $\begin{array}{l}\text { Yes (13, } \\
68.4 \%)\end{array}$ & Yes $(22,95.7 \%)$ & Yes $(12,46.2 \%)$ & Yes $(7,70 \%)$ & Yes $(13,59.1 \%)$ & Yes $(8,66.7 \%)$ & Yes $(15,88.2 \%)$ & Yes $(13,100 \%)$ \\
\hline $\begin{array}{l}\text { Occupations, } \\
(\mathrm{n}, \%)\end{array}$ & $\begin{array}{c}\text { Housewife } \\
(5,26.3 \%) \\
\text { Officer (11, } \\
57.9 \%) \\
\text { Worker (1, } \\
5.3 \%) \\
\text { Retired } \\
(1,5.3 \%) \\
\text { Baby-sitter } \\
(1,5.1 \%)\end{array}$ & $\begin{array}{c}\text { Officer } \\
(9,39.1 \%) \\
\text { Worker } \\
(9,47.4 \%) \\
\text { Self-employment } \\
(4,17.4 \%) \\
\text { Retired } \\
(1,4.3 \%)\end{array}$ & $\begin{array}{c}\text { Housewife (10, } \\
38.5 \%) \\
\text { Officer } \\
(5,19.2 \%) \\
\text { Worker } \\
(2,7.7 \%) \\
\text { Self-employment } \\
(2,7.7 \%) \\
\text { Retired } \\
(4,15.4 \%) \\
\text { Baby-sitter }(3, \\
11.5 \%)\end{array}$ & $\begin{array}{c}\text { Officer }(2,20 \%) \\
\text { Worker } \\
(3,30 \%) \\
\text { Self- } \\
\text { employment } \\
(2,20 \%) \\
\text { Retired }(3,30 \%)\end{array}$ & $\begin{array}{c}\text { Housewife } \\
(8,36.4 \%) \\
\text { Officer } \\
(7,31.8 \%) \\
\text { Worker } \\
(2,9.1 \%) \\
\text { Self-employment } \\
(1,4.5 \%) \\
\text { Retired }(1,4.5 \%) \\
\text { Baby-sitter }(3, \\
13.6 \%)\end{array}$ & $\begin{array}{c}\text { Officer } \\
(3,25 \%) \\
\text { Worker } \\
(3,25 \%) \\
\text { Self- } \\
\text { employment } \\
(2,16.7 \%) \\
\text { Retired } \\
(4,33.3 \%)\end{array}$ & $\begin{array}{c}\text { Housewife } \\
(2,11.8 \%) \\
\text { Officer } \\
(11,64.7 \%) \\
\text { Self-employment } \\
(2,11.8 \%) \\
\text { Baby-sitter } \\
(2,11.8 \%)\end{array}$ & $\begin{array}{c}\text { Officer } \\
(7,53.8 \%) \\
\text { Worker } \\
(2,15.4 \%) \\
\text { Self-employment } \\
(4,30.8 \%)\end{array}$ \\
\hline
\end{tabular}


Table 3. The WPAI parameters in patients and controls

\begin{tabular}{|c|c|c|c|c|c|c|c|}
\hline $\begin{array}{c}\text { SpA patients } \\
\text { (n: } 42) \text { Mean } \pm \text { SD }\end{array}$ & $\begin{array}{l}\text { PsA patients } \\
\text { (n: 36) Mean } \pm S\end{array}$ & $\begin{array}{l}\text { RA patients } \\
\text { (n: } 34) \\
\text { Mean } \pm \text { SD }\end{array}$ & $\begin{array}{l}\text { Control group } \\
\text { (n: } 30) \\
\text { Mean } \pm \text { SD }\end{array}$ & $\begin{array}{l}P \text { value } \\
\text { (Kruskal } \\
\text { Wallis) }\end{array}$ & $\begin{array}{c}p \\
\text { value } \\
\dagger\end{array}$ & $\begin{array}{l}p \\
\text { value } \\
\ddagger\end{array}$ & $\underset{\S}{p}$ \\
\hline \multicolumn{8}{|c|}{ Lost hours due to health problems (A2) } \\
\hline $8.15 \pm 12.3$ & $8.61 \pm 15.6$ & $1.65 \pm 4.6$ & $0.50 \pm 0.7$ & $0.002^{*}$ & $0.001^{*}$ & $0.002^{*}$ & 0.34 \\
\hline \multicolumn{8}{|c|}{ Lost hours due to other causes (A3) } \\
\hline $45.15 \pm 15.8$ & $45.55 \pm 15.4$ & $43.75 \pm 16.1$ & $41.75 \pm 7.2$ & 0.23 & 0.06 & 0.08 & 0.30 \\
\hline \multicolumn{8}{|c|}{ Percent lost work time caused by health problems (percentage of absenteeism) } \\
\hline $13.48 \pm 23.2$ & $19.03 \pm 30.1$ & $3.23 \pm 12.0$ & $1.12 \pm 3.7$ & $0.003^{*}$ & $0.002^{*}$ & $0.001^{*}$ & 0.32 \\
\hline \multicolumn{8}{|c|}{ Percent impairment during working caused by health problems (percentage of presenteeism) } \\
\hline $39.63 \pm 30.1$ & $32.22 \pm 22.1$ & $32.50 \pm 31.3$ & $5.71 \pm 12.3$ & $<0.001^{*}$ & $<0.001^{*}$ & $<0.001^{*}$ & $<0.001^{*}$ \\
\hline \multicolumn{8}{|c|}{ Percent total work impairment caused by health problems } \\
\hline $41.59 \pm 34.2$ & $42.97 \pm 31.1$ & $32.10 \pm 33.3$ & $6.42 \pm 13.8$ & $<0.001^{*}$ & $<0.001^{\star}$ & $<0.001^{*}$ & $0.01^{*}$ \\
\hline \multicolumn{8}{|c|}{ Percent activity impairment caused by health problems } \\
\hline $40.85 \pm 26.8$ & $31.90 \pm 19.9$ & $31.60 \pm 29.3$ & $6.07 \pm 14.5$ & $<0.001^{*}$ & $<0.001^{*}$ & $<0.001^{*}$ & $<0.001^{*}$ \\
\hline
\end{tabular}

Table 4. Variables that may affect percentage of presenteeism and absenteeism in patients with SpA, RA, and PsA

\begin{tabular}{|c|c|c|c|c|}
\hline \multirow[b]{2}{*}{ Variables } & \multicolumn{2}{|c|}{$\begin{array}{l}\text { Percentage of presenteeism } \\
\text { (Adjusted } R^{2}: 0.458 \text { ) }\end{array}$} & \multicolumn{2}{|c|}{$\begin{array}{l}\text { Percentage of absenteeism } \\
\quad \text { (Adjusted } R^{2}: 0.141 \text { ) }\end{array}$} \\
\hline & $\beta$ & $p$ value & $\beta$ & $p$ value \\
\hline Age & -0.23 & 0.09 & -0.08 & 0.44 \\
\hline Gender & -0.02 & 0.85 & -0.13 & 0.18 \\
\hline Disease activity & 0.19 & 0.21 & -0.03 & 0.75 \\
\hline Functional status & 0.36 & $0.02^{\dagger}$ & 0.42 & $<0.001^{\dagger}$ \\
\hline Disease duration & 0.06 & 0.66 & -0.11 & 0.26 \\
\hline Severity of pain & -0.02 & 0.90 & 0.28 & $\mathbf{0 . 0 2} 2^{\dagger}$ \\
\hline
\end{tabular}

SpA: Spondyloarthritis, PsA: Psoriatic arthritis, RA: Rheumatoid arthritis, $\dagger: p<0.05$ (significant)

Table 5. The correlation of WPAI parameters with fatigue, depression, and quality of life

\begin{tabular}{|c|c|c|c|c|}
\hline & & $\begin{array}{c}\text { Percent lost work time caused by } \\
\text { health problems (percentage of } \\
\text { absenteeism) }\end{array}$ & $\begin{array}{c}\text { Percent impairment during } \\
\text { working caused by health } \\
\text { problems (percentage of } \\
\text { presenteeism) }\end{array}$ & $\begin{array}{l}\text { Percent total work } \\
\text { impairment caused } \\
\text { by health problems } \\
\text { (productivity loss) }\end{array}$ \\
\hline \multirow{2}{*}{ FSI-intensity } & rho & 0.40 & 0.61 & 0.56 \\
\hline & $p$ & $<0.001^{\dagger}$ & $<0.001^{\dagger}$ & $<0.001^{\dagger}$ \\
\hline \multirow{2}{*}{ FSI-duration } & rho & 0.30 & 0.57 & 0.45 \\
\hline & $p$ & $0.01^{\dagger}$ & $<0.001^{\dagger}$ & $<0.001^{\dagger}$ \\
\hline \multirow{2}{*}{$\begin{array}{l}\text { FSI-interference with } \\
\text { quality of life }\end{array}$} & rho & 0.49 & 0.65 & 0.63 \\
\hline & $p$ & $<0.001^{\dagger}$ & $<0.001^{\dagger}$ & $<0.001^{\dagger}$ \\
\hline \multirow{2}{*}{ BDI } & rho & -0.24 & 0.45 & 0.50 \\
\hline & $p$ & $0.04^{\dagger}$ & $<0.001^{\dagger}$ & $<0.001^{\dagger}$ \\
\hline \multirow{2}{*}{ SF36 physical functioning } & rho & -0.37 & -0.63 & -0.63 \\
\hline & $p$ & $0.001^{\dagger}$ & $<0.001^{\dagger}$ & $<0.001^{\dagger}$ \\
\hline \multirow{2}{*}{ SF36 role-physical } & rho & -0.49 & -0.49 & -0.49 \\
\hline & $p$ & $<0.001^{\dagger}$ & $<0.001^{\dagger}$ & $<0.001^{\dagger}$ \\
\hline \multirow{2}{*}{ SF36 bodily pain } & rho & -0.50 & -0.62 & -0.61 \\
\hline & $p$ & $<0.001^{\dagger}$ & $<0.001^{\dagger}$ & $<0.001^{\dagger}$ \\
\hline \multirow{2}{*}{ SF36 general health } & rho & -0.29 & -0.58 & -0.56 \\
\hline & $p$ & $0.001^{*}$ & $<0.001^{\dagger}$ & $<0.001^{\dagger}$ \\
\hline \multirow{2}{*}{ SF36 vitality } & rho & -0.39 & -0.49 & -0.56 \\
\hline & $p$ & $0.001^{\dagger}$ & $<0.001^{\dagger}$ & $<0.001^{\dagger}$ \\
\hline \multirow{2}{*}{ SF36 social functioning } & rho & -0.51 & -0.46 & -0.48 \\
\hline & $p$ & $<0.001^{\dagger}$ & $<0.001^{\dagger}$ & $<0.001^{\dagger}$ \\
\hline \multirow{2}{*}{ SF36 role-emotional } & rho & -0.54 & -0.43 & -0.50 \\
\hline & $p$ & $<0.001^{\dagger}$ & $<0.001^{\dagger}$ & $<0.001^{\dagger}$ \\
\hline \multirow{2}{*}{ SF36 mental health } & rho & -0.29 & -0.36 & -0.38 \\
\hline & $p$ & $0.001^{*}$ & $<0.001^{\dagger}$ & $<0.001^{\dagger}$ \\
\hline
\end{tabular}

WPAI: Work Productivity and Activity Impairment, BDI: Beck Depression Inventory, SF36: Short Form-36, Spearman's rho correlation coefficient $+: p<0.05$ (significant) 
than the controls in the current study. We found higher percent of absenteeism in SpA and PsA patients than in the controls. Also, percent of presenteeism, percent total work impairment, and percent activity impairment caused by health problems were significantly higher in SpA, PsA, and RA patients than in the controls. The FSI, SF 36, and BDI scores were significantly correlated with the WPAI. Regression analysis showed negative effect of poor functional status on percentage of absenteeism and presenteeism, and the impact of pain severity on percentage of absenteeism.

The highest rate of employed individuals in the SpA group was due to the higher rate of men in SpA group, because most of the women in other patient groups were housewives. However, in the study by Massardo et al.(24) on RA patients, it was reported that approximately $\% 20$ of women working outside changed their occupational status to housewives because of their health problems. They pointed out that some women were necessarily housewives as a consequence of limitations due to their disease. Another reason for higher employment rates in the SpA group is the lower age of patients than ones with PsA and RA. In ASAS COMOrbidities in SpondyloArthritis (ASAS-COMOSPA) study(25), a meta-analysis which was performed to evaluate work participation in $\mathrm{SpA}$ across various countries. In this meta-analysis, the rate of employment in Turkish SpA patients was reported as $54 \%$ which is lower than our finding. In another study from Turkey, the rate of employment was reported as 60\% in SpA patients(5). In a study conducted on $133 \mathrm{SpA}$ patients in the United Kingdom, $31 \%$ of the patients were unable to work due to disease and \%15 reported work modifications such as decrease in working hours and changing the job(26). In a study on an early RA cohort from Argentina, the rate of employment was $89 \%$, although the average disease duration was rather short, 7 months(27).

In the present study, percentage of absenteeism was $13 \%$ in $\mathrm{SpA}, 19 \%$ in PsA, and 3\% in RA patients. Percentage of presenteeism was $40 \%$ in SpA, 32\% in PsA, and 33\% in RA patients. Percentage of absenteeism was much lower than percentage of presenteeism. This might result from difficulty in taking time off work in Turkey. In a similar study on a cohort of 400 patients with RA, AS, and psoriasis, no statistically significant difference was reported in terms of absenteeism, presenteeism, and total work impairment across three groups. Percentage of presenteeism were $40.3 \%, 33.0 \%$, and $54.2 \%$ in the RA, AS groups and the PsA subgroup within psoriasis patients respectively(28). In the study by Sruamsiri et al.(6) on 500 Japanese patients with RA, percentage of absenteeism and percentage of presenteeism were remarked to be $1 \%$ and $23 \%$, respectively. Similar to our study, percentage of absenteeism was lower than percentage of presenteeism. In another study from Japan, Anno et al.(1) reported a percentage of absenteeism of $15 \%$ and percentage of presenteeism as slightly higher than $40 \%$. The WPAI was used for measuring absenteeism and presenteeism in both studies from Japan. However, Anno et al. (1) reported no significant difference in percentage of absenteeism and percentage of presenteeism between RA patients and controls. In our study, 'percentage of absenteeism' was significantly higher only in SpA and PsA patients which may be explained by the lower patient number and female predominance in the RA group. 'Percentage of presenteeism', 'percent total work impairment caused by health problems and 'percent activity impairment caused by health problems' were found to be significantly higher in SpA, PsA, and RA patients than in controls. Since A3 was defined as 'lost hours resulting from other causes', no significant difference in $\mathrm{A} 3$ among groups was a result we expected. When the patients were assessed according to A2, namely 'lost hours because of health problems', SpA and PsA patients scored significantly higher than the controls. Besides, pain severity was higher in SpA and PsA patients, although disease activity was comparable in each of the three groups. Moreover, multiple regression analysis showed effect of pain severity on only 'percentage of absenteeism, but not 'percentage of presenteeism. These findings suggest that absenteeism in SpA and PsA patients may be associated with the dysfunctions of the peripheral or central nervous systems. The high rate of central sensitivity syndromes (such as fibromyalgia) in rheumatic diseases points out that neuropathic pathways may conduce to chronic pain in patients with rheumatic diseases in addition to nociceptive mechanisms. Centralized pain/fibromyalgia is commonly reported in patients with rheumatic diseases; at rates of 13 to $40 \%$ in RA and 10 to $30 \%$ in SpA and PsA patients(29). Rheumatic patients with concurrent fibromyalgia describe more severe pain and they have higher disease activity scores, worse outcomes, worse emotional health, and poorer sleep quality than those without fibromyalgia $(30,31)$. The fact that we disregarded the presence of fibromyalgia and neuropathic pain in rheumatic patients can be considered as a limitation of our study.

In our study, clinical parameters of the patients including age, gender, disease activity, and disease duration had no impact on percentage of absenteeism and percentage of presenteeism. It was found that pain negatively affected percentage of absenteeism. Michaud et al.(32) determined a positive relationship between pain reduction and improvement in work productivity in RA patients treated with baricinitib. In a study from Canada, it was reported that pain was related with percentage of absenteeism and presenteeism in patients with early RA(33). In contrast to our study, Sag et al.(5) found that disease activity was associated with productivity loss in Turkish AS patients where they evaluated disease activity using the BASDAI.

Based on our findings, functional disability had significant effect on percentage of absenteeism and percentage of presenteeism in patients with RA, PsA, and SpA. Similarly, Bansback et al.(33) reported an association between functional status and percentage of absenteeism and percentage of presenteeism in the 
patients with early RA. Also Sag et al. (5) demonstrated that labor loss was related with functional disability determined by the Bath Ankylosing Spondylitis Functional Index in their study on patients with AS. Functional status and disease activity were shown to affect work productivity in the study by Kruntorádová et al. which has a similar design to our study. However, disease activity was rather high in that study among all groups of RA, AS, and psoriasis which may account for the different results regarding effect of active disease on work productivity in our study(28).

Fatigue is multifactorial and its evaluation needs a multifaceted scale which analyses all dimensions of fatigue. Therefore, we used the FSI to assess intensity and continuance and as well as its perceived interference with quality of life concerning routine activities, concentration and memory, and emotional functions. In our study, all FSI subgroups were found to be correlated with A2, percentage of absenteeism, percentage of presenteeism, percent total work impairment and percent activity impairment caused by health problems. Our results were consistent with prior studies which have reported that fatigue is associated with work productivity. In a study from the USA(32) evaluating the relationship between Functional Assessment of Chronic Illness TherapyFatigue (FACIT-F) and WPAI in RA patients, reduction in fatigue was found to be associated with improved work productivity. Similarly, Enns et al.(34) demonstrated an association of pain with percentage of absenteeism and presenteeism in chronic inflammatory diseases including RA. Also, in another study by Hazes et al.(35), a clear relationship was determined between amelioration in fatigue and improvement in work productivity in RA patients on certolizumab pegol.

In our study, all parameters of SF-36 were found to be correlated with A2, percentage of absenteeism and presenteeism, percent total work impairment and percent activity impairment caused by health problems. In the study of Sag et al.(5), the impairment in the work productivity was correlated only with vitality subgroup of SF-36 in patients with AS. In another study from Netherlands, work productivity was found to be associated with quality of life determined by the RAND36 in terms of mental health, physical functions, and pain in RA patients(10).

We found that depression was correlated with percentage of absenteeism and presenteeism, percent total work impairment, and percent activity impairment caused by health problems. Similar findings were reported by Sag et al.(5) in AS patients where they assessed depression using the Hospital Anxiety and Depression Scale.

Although there are various studies which address the work productivity in SpA, RA, and PsA; our study has the merit to compare productivity loss in three rheumatic disease groups along with a control group. Preferring the WPAI is another strength of our study since it measures both productivity loss due to disease- related absence from work and loss resulting from reduced work performance related to the disease. Furthermore, it allows evaluation of productivity both in employed and unemployed patients. Not matching age, gender, and employment status in all patient groups and controls is a limitation of the current study. Other limitations include not using disease specific WPAI scales and not assessing comorbid situations properly.

\section{CONCLUSION}

In the current study where we evaluated work productivity in SpA, PsA, and RA patients, we have determined that the percentage of absenteeism was lower than percentage of presenteeism. Functional status, quality of life, and fatigue, but not disease activity had significant relationships with absenteeism and presenteeism. Besides, percentage of presenteeism was higher in SpA, PsA, and RA patients than in controls.

\section{ACKNOWLEDGEMENTS}

This study has no financial support. Authors declare no conflicts of interest.

\section{AUTHORS' CONTRIBUTION}

Concept and Design: İsmihan SUNAR, Yeşim GARİP, Sebnem ATAMAN

Data acquisition: İsmihan SUNAR

Analysis: Yeșim GARIP

Literature review and search: Yeşim GARİP, İsmihan SUNAR

Composition of the article: İsmihan SUNAR, Yeşim GARIP, Sebnem ATAMAN

\section{REFERENCES}

1.)Anno $S$, Sugioka $Y$, Inui $K$, et al. Evaluation of work disability in Japanese patients with rheumatoid arthritis: from the TOMORROW study. Clin Rheumatol. 2018;37:1763-71

2.)Hresko A, Lin TC, Solomon DH. Medical Care Costs Associated With Rheumatoid Arthritis in the US: A Systematic Literature Review and Meta-Analysis. Arthritis Care Res (Hoboken). 2018;70:1431-8.

3.)Xavier RM, Zerbini CAF, Pollak DF, et al. Burden of rheumatoid arthritis on patients' work productivity and quality of life. Advances in Rheumatology. 2019;59:47.

4.)Walsh JA, McFadden ML, Morgan MD, et al. Work productivity loss and fatigue in psoriatic arthritis. J Rheumatol. 2014;41:1670-4. 5.)Sağ S, Nas K, Sağ MS, et al. Relationship of work disability between the disease activity, depression and quality of life in patients with ankylosing spondylitis. J Back Musculoskelet Rehabil. 2018;31:499-505.

6.)Sruamsiri R, Mahlich J, Tanaka E, et al. Productivity loss of Japanese patients with rheumatoid arthritis - A cross-sectional survey. Mod Rheumatol. 2018;28:482-9.

7.)Tillett W, Lin CY, Zbrozek A, et al. A Threshold of Meaning for Work Disability Improvement in Psoriatic Arthritis Measured by the Work Productivity and Activity Impairment Questionnaire. Rheumatol Ther. 2019;6:379-91.

8.)Nikiphorou E, RamiroS. Work Disability in Axial Spondyloarthritis. Curr Rheumatol Rep. 2020;22:55.

9.)Hann DM, Jacobsen PB, Azzarello LM, et al. Measurement of fatigue in cancer patients: development and validation of the Fatigue Symptom Inventory. Qual Life Res. 1998;7:301-10. 
10.)van Vilsteren M, Boot CR, Knol DL, et al. Productivity at work and quality of life in patients with rheumatoid arthritis. BMC Musculoskelet Disord. 2015;16:107.

11.)Sieper J, Rudwaleit M, Baraliakos $X$, et al. The Assessment of SpondyloArthritis international Society (ASAS) handbook: a guide to assess spondyloarthritis. Ann Rheum Dis. 2009;68 Suppl 2:ii1-44.

12.)Akkoc Y, Karatepe AG, Akar S, et al. A Turkish version of the Bath Ankylosing Spondylitis Disease Activity Index: reliability and validity. Rheumatol Int. 2005;25:280-4.

13.)Taylor W, Gladman D, Helliwell P, et al. Classification criteria for psoriatic arthritis: development of new criteria from a large international study. Arthritis Rheum. 2006;54:2665-73.

14.)Schoels MM, Aletaha D, Alasti F, et al. Disease activity in psoriatic arthritis (PsA): defining remission and treatment success using the DAPSA score. Ann Rheum Dis. 2016;75:811-8.

15.)Aletaha D, Neogi T, Silman AJ, et al. 2010 Rheumatoid arthritis classification criteria: an American College of Rheumatology/ European League Against Rheumatism collaborative initiative. Arthritis Rheum. 2010;62:2569-81.

16.) Prevoo ML, van 't Hof MA, Kuper $\mathrm{HH}$, et al. Modified disease activity scores that include twenty-eight-joint counts. Development and validation in a prospective longitudinal study of patients with rheumatoid arthritis. Arthritis Rheum. 1995;38:44-8. 17.)Price DD, McGrath PA, Rafii A, et al. The validation of visual analogue scales as ratio scale measures for chronic and experimental pain. Pain. 1983;17:45-56.

18.)Küçükdeveci $A A$, Sahin $H$, Ataman $S$, et al. Issues in crosscultural validity: example from the adaptation, reliability, and validity testing of a Turkish version of the Stanford Health Assessment Questionnaire. Arthritis Rheum. 2004;51:14-9.

19.)Bilir Kaya B, İçağasığlu A. Reliability and validity of the Turkish version of short form 36 (SF-36) in patients with rheumatoid arthritis. Journal of Surgery and Medicine. 2018;2:11-6.

20.)Beck AT, Ward $\mathrm{CH}$, Mendelson $\mathrm{M}$, et al. An inventory for measuring depression. Arch Gen Psychiatry. 1961;4:561-71.

21.)Reilly MC, Zbrozek AS, Dukes EM. The validity and reproducibility of a work productivity and activity impairment instrument. Pharmacoeconomics. 1993;4:353-65.

22.) Oksuz E, Malhan S, Tulunay F. Reliability, and validity of The Fatigue Symptom Inventory. Value in Health. 2008;11:A426.

23.)Donovan KA, Jacobsen PB. The Fatigue Symptom Inventory: a systematic review of its psychometric properties. Support Care
Cancer. 2010;19:169-85.

24.)Massardo L, Aguirre V, García ME, et al. Clinical expression of rheumatoid arthritis in Chilean patients. Semin Arthritis Rheum. 1995;25:203-13.

25.)Manica S, Sepriano A, Ramiro S, et al. Work participation in spondyloarthritis across countries: Analysis from the ASASCOMOSPA study. Annals of the Rheumatic Diseases. 2018;1303-10. 26.)Barlow JH, Wright CC, Williams B, et al. Work disability among people with ankylosing spondylitis. Arthritis Rheum. 2001;45:424-9.

27.)Citera G, Ficco HM, Alamino RS, et al. Work disability is related to the presence of arthritis and not to a specific diagnosis. Results from a large early arthritis cohort in Argentina. Clin Rheumatol. 2015;34:929-33.

28.)Kruntorádová K, Klimeš J, Šedová L, et al. Work Productivity and Costs Related to Patients with Ankylosing Spondylitis, Rheumatoid Arthritis, and Psoriasis. Value Health Reg Issues. 2014;4:100-6.

29.)Guler MA, Celik OF, Ayhan FF. The important role of central sensitization in chronic musculoskeletal pain seen in different rheumatic diseases. Clin Rheumatol. 2020;39:269-74.

30.)McWilliams DF, Walsh DA. Pain mechanisms in rheumatoid arthritis. Clin Exp Rheumatol. 2017;35 Suppl 107:94-101.

31.)Wolfe F, Michaud K. Severe rheumatoid arthritis (RA), worse outcomes, comorbid illness, and sociodemographic disadvantage characterize ra patients with fibromyalgia. J Rheumatol. 2004;31:695-700.

32.)Michaud K, Pope JE, Emery P, et al. Relative Impact of Pain and Fatigue on Work Productivity in Patients with Rheumatoid Arthritis from the RA-BEAM Baricitinib Trial. Rheumatol Ther. 2019;6:409-19.

33.)Bansback $\mathrm{N}$, Zhang $\mathrm{W}$, Walsh $\mathrm{D}$, et al. Factors associated with absenteeism, presenteeism and activity impairment in patients in the first years of RA. Rheumatology (Oxford). 2012;51:375-84.

34.)Enns MW, Bernstein CN, Kroeker K, et al. The association of fatigue, pain, depression and anxiety with work and activity impairment in immune mediated inflammatory diseases. PLoS One. 2018;13:e0198975.

35.)Hazes JM, Taylor $\mathrm{P}$, Strand $\mathrm{V}$, et al. Physical function improvements and relief from fatigue and pain are associated with increased productivity at work and at home in rheumatoid arthritis patients treated with certolizumab pegol. Rheumatology (Oxford). 2010;49:1900-10.

Ankara Eğt. Arş. Hast. Derg. (Med. J. Ankara Tr. Res. Hosp.), 2021 ; 54(2) : 313-320

Ethics committee approval was obtained from Ankara University Ethics Committee with date of 16 April 2018 and number of 07-43118. All participants gave informed consents. 